\title{
Kunst og naturvidenskab under samme tag
}

\section{Kollokvium om at udstille kunst og naturvidenskab. Steno Museet, Danmarks Videnskabshistoriske Museum, Århus, 25. september 2006}

Mette Kia Krabbe Meyer* og Hanne Teglhus*

Title: Art and the natural sciences under the same roof.

Abstract: In the fall of 2006, the Steno Museum (Aarhus, Denmark) exhibited the installation Room One created by the American artist Rosamond Purcell. This installation consists of a full-size model of Museum Wormianum, the Danish physician Ole Worm's curiosity cabinet, dating from the 17th century. This is a work of art - yet it depicts a naturalist's laboratory. When one adds that it has also been called the first museum in Denmark, it seemed an obvious step to make the artwork the occasion of a symposium on the relationship between art, science and museums.

At this symposium, the artist, along with a number of science historians and museum curators, discussed the definitions of art and science then and now, and spoke about the attempts to transcend the disciplinary boundaries that take place within the museums. Different ways of exhibiting were brought into focus, and Purcell's installation formed the basis for many interesting discussions about the museum as a place of learning and of aesthetic experience.

Keywords: Art, natural sciences, Ole Worm, interdisciplinary fields, museum, Room One, classification.

Skal vi udstille kunsten på kunstmuseerne og naturvidenskaben på de naturvidenskabelige museer, eller giver den klassiske fagopdeling ikke mening længere? Er vi på vej bort fra det belærende museum, der har en snæver faghistorisk profil og formidler én objektiv sandhed til de besøgendes fornuft. Og på vej hen imod det tværfaglige, ikke docerende museum, der på en sanselig og subjektiv måde engagerer den besøgende i spørgsmål og emner med en bred kulturel appel. Det var spørgsmål som disse, der blev diskuteret på kollokviet "Room One. Ole Worm. A Work of Art in a History of Science Museum".

Anledningen til at tage forholdet mellem naturvidenskab og kunst op til diskussion og til at se nærmere på, hvordan begge dele bliver udfordret på museerne, var lånet af den amerikanske kunstner Rosamond Purcells installation "Room One". Værket er en genfor- 
116 tolkning af lægen og oldtidsforskeren Ole Worms "Museum Wormianum", et rum, der indeholder mineraler, udstoppede dyr og kunstgenstande m.m. samlet i den sene, danske renæssance. "Room One" er skabt på grundlag af det kobberstik af rummet, der optræder i Worms eget katalog over sit museum. ${ }^{1}$ På Steno Museet blev Purcells installation og Worms katalog suppleret med andre af Worms publikationer samt en samling portrætmalerier, der forestillede Worms slægt.

Udstillingen var museets bidrag til renæssanceåret 2006, og museumsinspektør og udstillingens kurator, Hanne Teglhus' intention med den var ikke blot at fortælle historien om en videnskabsmand og hans opfattelse af videnskabelighed, men også at skabe refleksion over videnskabens væsen hos den besøgende. Det var oplevelsen af, at "Room One" på en anden måde end en traditionel udstilling kunne skabe omtanke og engagement hos mange forskellige mennesker, der fik museet til at arbejde for, at kunstværket skulle ind på Steno Museet, der ellers er museum for den eksakte videnskab.

"Room One" gav muligheden for en sanselig oplevelse af et sted, der ikke var "Museum Wormianum", men en pendant til det. Det var en fascinerende oplevelse af at få indblik i en anden tids tankeunivers, men også et memento om, hvordan vi engang selv bliver en fortid, nogen kan kaste et uforstående blik tilbage på. Samtidig skabte "Room One" også en undren over, hvorfor Worm udstillede sine ting, som han gjorde, og refleksion over, hvordan nyere museer har deres oprindelse i "Museum Wormianum". Hvad har ændret sig gennem tiderne, og hvad siger "Museum Wormianum" os i dag, hvor vi er i gang med at udvikle nutidens og fremtidens museer? Disse spørgsmål synes vi kunne være spændende at tage op til diskussion både med ophavskvinden bag "Room One" og med en bredere skare af museumsfolk og videnskabshistorikere, og vi havde derfor indbudt til heldagskollokviet.

\section{DIREKTE OBSERVATION AF FENOMENERNE ELLER EN SAMLING AF MARKVÆRDIGHEDER}

Purcell var dagens første oplægsholder, og hun tog udgangspunkt i de spørgsmål, hun som kunstner havde været stillet overfor i arbejdet med at etablere "Room One". Siden Purcell første gang så kobberstikket af "Museum Wormianum", havde hun været fascineret af samlingen og dens opstilling. Hun begyndte med det samme at fundere over, hvordan den todimensionale tegning kunne transformeres til et tredimensionelt rum. På kollokviet fortalte hun om, hvordan hun forsøgte at skabe en så naturtro gengivelse som muligt, samtidig med at hun tog en række subjektive, æstetiske valg. Det medførte på kollokviet en diskussion af, hvad en realistisk genskabelse egentlig er. Der blev talt om, hvorvidt rummet på stikket optræder spejlvendt, fordi bl.a. enhjørningehornene har snoninger, der løber den modsatte vej af snoningerne på ægte narhvalstænder. Og det blev berørt, hvad det mere generelt betyder at anvende en illusionsskabende scenografi i museet. Under arbejdet med "Room One" havde Purcell endvidere spekuleret over Worms opstillingssystemer. Hun mente, at Worm ønskede at observere alle fænomener direkte og ikke blot danne sig spekulative forestillinger om dem, og at Worm dermed afsøgte grænserne mellem myter og fakta.

Adjunkt ved Medicinsk Museion (tidligere Medicinsk-Historisk Museum) i København, Camilla Mordhorst, tog i sit oplæg udgangs- 
punkt i Worms egen korrespondance vedrørende indsamlingen af uforklarlige genstande til sit museum. Worm beskriver $\mathrm{i}$ et brev, hvordan en norsk kone, der allerede havde 12 børn, under store pinsler fødte et hønseæg. Ole Worms kommentar til erhvervelsen af dette $æ g$ viser, at han mente, det var underligt, at en kvinde kunne føde et sådant tilsyneladende helt ordinært hønseæg, men da han samtidig modtog skriftlig erklæring om hændelsens rigtighed, havde han ingen betænkelighed ved at lade det indgå i museets samling af øvrige mærkværdigheder. Camilla Mordhorst fremhævede, at Worm ikke indsamlede ting, som han mente, han kunne give en fornuftig forklaring på. Han var mere interesseret i ting, han netop ikke umiddelbart kunne forstå, men hvis egenskaber han ønskede at efterprøve. Hans museum var med andre ord stedet, hvor han kunne undersøge nye underlige naturalier og fænomener, og dermed forsøge at bibringe ny viden og nye erfaringer til den traditionelle og alment accepterede viden. Mordhorst var således enig med Purcell i, at Worm var eksperimenterende og således var med i den naturvidenskabelige revolution, der satte empirien i højsæde. Samtidig lagde hun mere end Purcell vægt på, at Worm samtidig afsøgte empiriens og klassifikationens grænser.

\section{DEN GODE UDSTILLING OG OPBLØDNING AF FAGGRÆNSER}

Museumsinspektør Jan Gruwier Larsen fra Naturhistorisk Museum i Århus problematiserede i sit oplæg, "The Science-Arts Continuum in Exhibitions", at man skelnede så skarpt mellem kunst og naturvidenskab. Han ville hellere fokusere på, hvordan man skaber den gode udstilling end på at finde forskelle mellem kunst og videnskab. På kollokviet var at etablere et begrænsende videnskabs- eller kunstbegreb, og at begge dele, men måske især kunsten er defineret institutionelt. En rekonstruktion af "Museum Wormianum", der var skabt af museets håndværkere som en illustration af en renæssancevidenskabsmands laboratorium, ville f.eks. ikke blive defineret som et kunstværk, selvom den var identisk med "Room One".

Både adjunkt i videnskabshistorie fra Steno Instituttet i Århus, Kristian Hvidtfelt Nielsen, og museumsinspektør på Steno Museet, Mette Kia Krabbe Meyer, satte fagopdelingen i et historisk, museologisk perspektiv. De fortalte om, hvordan museerne i sin tid blev grundlagt som udstillingssteder for fagene kunst, zoologi, geologi, medicin og kulturhistorie, men også om hvordan man ser tendenser til, at grænserne mellem fagområderne udviskes i nutidens udstillinger. Hvidtfelt Nielsen fortalte om kuratorernes Peter Weibels og Bruno Latours udstillinger "Iconoclash" og "Making Things Public", udstillinger, der satte en række samfundspolitiske emner på dagsordenen og gjorde det ved at blande genstande og information fra religion, videnskab, teknologi, politik. Krabbe Meyer præsenterede planerne for Steno Museets udvidelse, "Inspiratorium". Visionen bag "Inspiratorium" er at skabe et oplevelses- og læringssted, der kombinerer udstilling og aktivitet og som sætter naturvidenskaben i et kulturelt perspektiv. Med udgangspunkt i en af udstillingssalene, der handler om menneske og teknologi, fortalte hun om, hvordan videnskabshistorien og kulturhistorien skal flettes sammen i debatterende opstillinger, der også kan blande genstande og perspektiver fra forskellige fagområder. Hun kom også ind på, at kuratoren i den forbindelse 


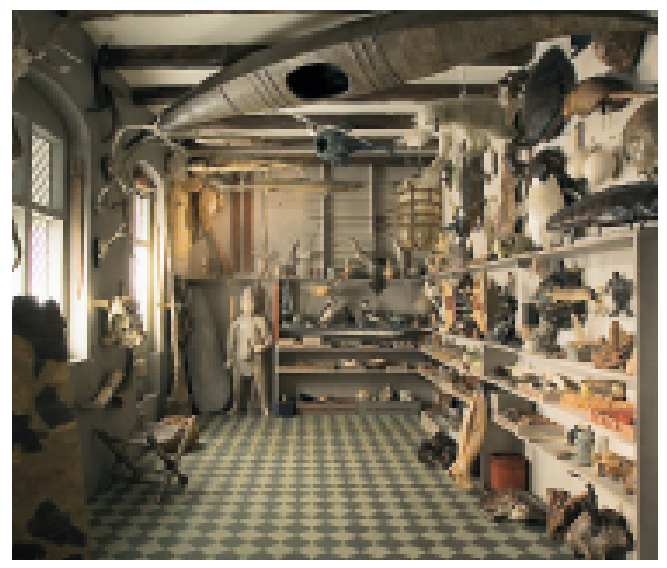

Installation af Rosamond Purcell. Fotoet viser installationen "Room One, Ole Worm", som den fremstair ved opbygningen på Steno Museet i Arhus, Danmark, efterarret 2006. Foto: Lars Kruse, $A U$-foto.

skal optræde som en slags scenograf, der sætter emnerne i scene på en effektfuld vis i rummet og rørte dermed ved et løbende diskussionsemne, seminaret igennem. Mange vendte tilbage til det slægtskab, der er mellem kuratoren og nogle former for kunstnerisk praksis, nemlig at der er tale om en rumlig iscenesættelse, der engagerer beskueren kropsligt og mentalt. Hvor Gruwier Larsen og Hvidtfelt Nielsen gerne så, at grænserne mellem kunst og videnskab blev udviskede, understregede Krabbe Meyer, at det i "Inspiratorium" også gjaldt om at bruge kunsten som en bevidst kontrast, eller som et anderledes perspektiv på videnskaben.

\section{KRITIK AF DET DIDAKTISKE MUSEUM}

Der var generel enighed om, at museerne for længe har været spændt for didaktikkens vogn. Udstillinger har haft et belærende sigte, og de har indeholdt hobe af fakta, som de besøgende skulle tage til sig. Særligt Gruwier Larsen havde en høne at plukke med kuratorerne på såvel kunstmuseerne som de naturvidenskabelige museer, som han mente havde reduceret museet til en skolestue. Vi diskuterede, hvorvidt "Museum Wormianum" i sin tid blev set som en samling med en tilknyttet fast tolkning af naturen eller som en studiesamling, der blev anvendt til at stille spørgsmål til vedtagne normer og teorier. Mordhorst lagde vægt på, at "Museum Wormianum" for hende var interessant, fordi det var et laboratorium, hvor man kunne undersøge naturen. Det var og er så spændende, fordi Worm turde udstille videnskabens usikkerhed. Netop denne egenskab gør det til en vigtig inspirationskilde for nutiden. Efter de seneste hundrede år, hvor det belærende har været på dagsordenen, er det på tide, at vi med inspiration fra blandt andet Worm tager mod til os og tør gøre museet til et sted, hvor fremtidens spørgsmål stilles, og ikke kun et sted, hvor fortidens svar gives, mente Mordhorst. I den nyeste bio-medicin er der mange genstande og fænomener, som vi ikke har en klar definition af eller holdning til. I stedet for at vente på, at historikerne engang skriver bio-medicinens historie, skal Medicinsk Museion, der har biomedicinens udvikling fra 1955 til 2005 som et satsningsområde, allerede nu indsamle og udstille biomedicinen $\mathrm{i}$ al dens mangfoldighed og ubestemthed.

Kritikken af den didaktiske tradition indebar også en kort tilbagevenden til udstillingernes konkrete indretning. Hvor man tidligere primært har stillet genstande op på en tilsyneladende objektiv måde og formidlet et fagligt indhold i tekst, er der nu en forståelse for, at man alene med en iscenesættelse af genstande kan stille spørgsmål og få de besøgende til at 
skabe historier. Det fremgik tydeligt af Krabbe Meyers oplæg om "Inspiratorium”. I "Inspiratorium" skal fortællinger, associationer, lyd, tekst, billeder, genstande og aktiviteter kombineres i en scenografi, som kan opleves med alle sanser, og som lægger op til debat.

\section{STADIG AKTUELT TEMA}

Kollokviet "Room One. Ole Worm. A Work of Art in a History of Science Museum" satte således naturvidenskabens og kunstens muligheder til debat. Der blev diskuteret videnskabs- og kunstbegreb, og vi kom ind på de mange forskellige konstellationer, kunst og videnskab kan indgå i. Der blev sat fokus på udviskningen af grænserne mellem forskellige fagområder. Både idet der blev anlagt et videnskabshistorisk perspektiv og spurgt til, hvordan definitionen af videnskaben forløber gennem tiden. Hvordan er den naturvidenskab, vi tager for givet, blevet til? Hvornår er noget videnskab, og hvornår er det ikke? Men også ved at sætte museernes rolle til debat. Generelt var der et ønske om et større mål af tværfaglighed, dristighed, aktualitet og debat på museerne. Man ønskede at komme væk fra den belærende udstilling, der bombarderer den sagesløse besøgende med fagligt skyts fra elfenbenstårnet. Visionen er nu museer, hvor bredere samfundsmæssige emner tages op, hvor medier og fagområder blandes, og man ikke kun taler til den besøgendes intellekt, men også til sanser og følelser. Det er ikke første gang, man hører det, vil nogen tænke, og ganske rigtigt. Visionen er langtfra ny, men den er ikke desto mindre stadig aktuel.

1. Ole Worm: Museum Wormianum seu historia rerum rariorum, tam naturalium, quam artificalium, tam domesticarum, quam exoticarum, que Hafnic Danorum in edibus authoris servantur. Amsterdam 1655.

*Hanne Teglhus er museumsinspektør, ekstern lektor, mag.art. på Steno Museet og Center for Museologi, Aarhus Universitet.

Address: C. F. Møllers Allé, bygning 1100, 8000 Arhus $C$.

E-mail: hanne.teglhus@si.au.dk

* Mette Kia Krabbe Meyer er ph.d., museumsinspektor på Steno Museet, Aarhus Universitet.

Address: C. F. Møllers Allé, bygning 1100, 8000 Arhus C. Privatadresse: Gothersgade 161, 3. th. 1123 København $K$.

E-mail:mette.kia@si.au.dk 